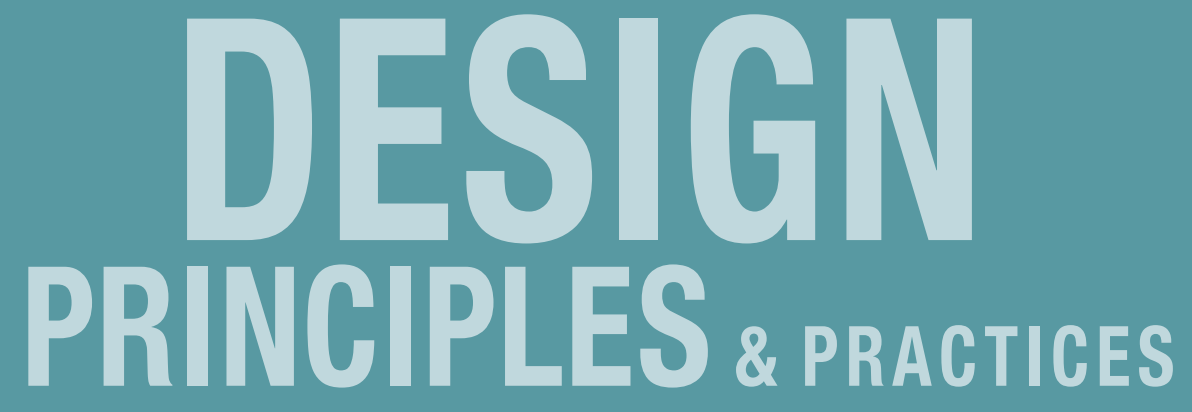
AN INTERNATIONAL

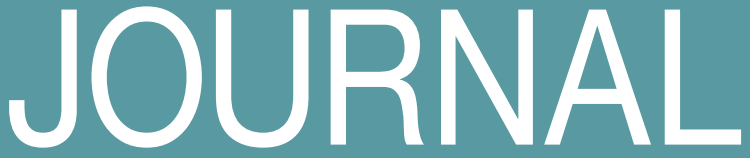

Volume 5

The Craze for Design Thinking: Roots, A Critique, and toward an Alternative

James Woudhuysen 
DESIGN PRINCIPLES AND PRACTICES: AN INTERNATIONAL JOURNAL http://www.Design-Journal.com

First published in 2011 in Champaign, Illinois, USA

by Common Ground Publishing LLC

www.CommonGroundPublishing.com

ISSN: 1833-1874

(C) 2011 (individual papers), the author(s)

(c) 2011 (selection and editorial matter) Common Ground

All rights reserved. Apart from fair dealing for the purposes of study, research, criticism or review as permitted under the applicable copyright legislation, no part of this work may be reproduced by any process without written permission from the publisher. For permissions and other inquiries, please contact

<cg-support@commongroundpublishing.com>.

DESIGN PRINCIPLES AND PRACTICES: AN INTERNATIONAL JOURNAL is peerreviewed, supported by rigorous processes of criterion-referenced article ranking and qualitative commentary, ensuring that only intellectual work of the greatest substance and highest significance is published.

Typeset in Common Ground Markup Language using CGPublisher multichannel typesetting system

http://www.commongroundpublishing.com/software/ 


\title{
The Craze for Design Thinking: Roots, A Critique, and toward an Alternative
}

\author{
James Woudhuysen, De Montfort University, England, UK
}

\begin{abstract}
Favouring orientation to and the participation of design users in the design process, Design Thinking (DT) has a long lineage. With the Cold War's end, the Internet's rise and Stanford University's turn to teaching DT (2005), this 'bottom up', demand-driven conception of design gained new adherents, going on to win mainstream status when advocated in the 'Harvard Business Review' in 2008. While some managers, especially in government, have since adopted DT rather uncritically, it has prompted a schism in design circles - one as grand, perhaps, as that between post-Modernism and Modernism back in the 1970s/1980s. Though DT has reached Latin America and Asia, critics such as Norman (US) and Verganti (Italy) are unanimous that DT has wrongly made consumer contexts, behaviours and needs seem preferable to what McCullagh (UK) describes as 'other drivers of innovation, including technical progress'. In DT, 'sustainability' tends to be taken for granted, and expensive prices are rarely considered. An alternative to DT is briefly outlined, which, it is hoped, can begin to address these defects.
\end{abstract}

Keywords: Design Thinking, Technological Innovation, Energy, Pharmaceuticals, IT, Happiness, Workplace Design, Ethical Design, Storytelling

\section{Introduction $^{1}$}

$\mathrm{I}$

N OCTOBER 2009, Pharmaceutical Executive magazine ran an article on innovation by design. ${ }^{2}$ Among 26 mentions of the word 'design', nine occurred in the phrase 'design thinking'. The article was written by two members of the Monitor Group, which is headquartered in Cambridge, Massachusetts, and is run by the world-renowned American management guru Michael Porter.

In a trade magazine, a serious article on design thinking - henceforth DT - is a step forward. What's more, Monitor has clients among some of the world's top international managers.

Its article begins by asserting that pharmaceuticals firms must confront 'multi-layered demands' and must, in particular, 'explore new business models while attending to their existing, highly profitable commercial model'. It suggests that designers excel at solving such challenges, and that DT could help pharmaceutical companies 'frame healthcare challenges holistically, taking into account the needs of all stakeholders'.

Such firms, it's maintained, should absorb the experience of customers and non-customers, and the contexts in which they live and act; should use cultural anthropologists, social scientists, and ethnographers to add to traditional market research; should draw connections to

\footnotetext{
${ }^{1}$ Thanks are due to Kevin McCullagh and Martyn Perks for comments on earlier drafts of this paper.

${ }^{2}$ Bansi Nagji and Matt Locsin, 'Innovation by design', Pharmaceutical Executive, October 2009, on http://www.monitorinnovation.com/downloads/InnovationByDesign-PharmaceuticalExecutiveOct2009Monitor.pdf. Nagji was a senior partner at Monitor, and leader of its global innovation practice.
}

Design Principles and Practices: An International Journal 
other fields of study and industries, and should get 'main insights from the market itself' through the rapid prototyping of new models with lead users and non-users in their natural environments.

Throughout, Monitor gives examples of DT in practice - both inside healthcare (the Mayo Clinic and Kaiser Permanente), and outside it (Procter \& Gamble). Inside pharmaceuticals, it contends, DT can help firms partner with doctors to help them run more successful business practices; can help budget-holders for health care explore 'dramatically different models of cooperation and risk management', and can give patients intuitive, clear information and convenient solutions that enable them to 'participate in their own care'. In its conclusions, the article notes:

'Of course, design capabilities are complements to, not substitutes for, the existing innovation capabilities of the [pharmaceutical] industry.'

Given the many, varied and substantial responsibilities that Monitor conferred upon DT, this careful sentence was well advised.

The same month as Monitor published, one leading US pharmaceutical company, Pfizer, announced its takeover of another, Wyeth, for $\$ 68$ billion. Interestingly, Pfizer was already quick to play up, if not DT, then certainly a key aspect of it - what is now widely known in medical circles as 'patient-centricity'. ${ }^{3}$ But by February 2010, something else happened: the company cut its 2012 budget for research and development (R\&D), the most important of its 'existing innovation capabilities', from more than $\$ 8$ billion to less than $\$ 7$ billion. Pfizer also announced the closure of its main laboratories outside the US, which are located in the $\mathrm{UK}^{4}$

Obviously the loss of up to 2400 jobs at Sandwich, Kent, cannot be laid at the door of DT. But the Pfizer story raises two key issues around the conclusion of Monitor's article:

1. Is DT, and a designerly orientation to users, really just a complement to, not a substitute for, $R \& D$ ?

2. When DT claims to facilitate partnership with, and the participation of, stakeholders of all descriptions, are these claims to be taken at face value?

Precise definitions of DT vary and are rather elusive. ${ }^{5}$ Here, Monitor's treatment of DT will have to suffice. Instead of definitions, this paper first examines the current craze for DT,

\footnotetext{
${ }^{3}$ See Pfizer, 'Pfizer and Wyeth become one: working together for a healthier world', press release, 16 October 2009, on http://media.pfizer.com/files/news/press_releases/2009/pfizer_wyeth_become_one_101609.pdf. IT companies active in the medical field also claim to be engaged in patient-centricity: see for example IBM Healthcare and life sciences, Patient-centric: the 21st Century Prescription for Healthcare, May 2006, on http://www03.ibm.com/industries/ca/en/healthcare/files/060516_PatientCentric_Briefing.pdf,

and Microsoft, 'Microsoft launches fund to enable patient-centric health solutions', Microsoft press release, 25 February 2008, on http://www.microsoft.com/presspass/press/2008/feb08/02-24HealthVaultFundPR.mspx

${ }^{4}$ Pfizer, 'Pfizer Reports Fourth-Quarter and Full-Year 2010 Results; Provides 2011 Financial Guidance and Updates 2012 Financial Targets', press release, 1 February 2011, on http://www.pfizer.com/news/press_releases/pfizer_press_releases.jsp\#guid=20110201006166en\&source=RSS_2011\&page $=1$

${ }^{5}$ For a flavour of differing views of DT, see Helen Walters, 'Inside the Design Thinking Process', Business Week, 14 December 2009, on http://www.businessweek.com/innovate/content/dec2009/id20091214_823878.htm, and Bill Moggridge, 'Design thinking: Dear Don...', Core 77, 2 August 2010, on http://www.core77.com/blog/columns/design_thinking_dear_don_17042.asp\#more
} 
and then looks at DT's historical emergence over the past 50 years, focusing mainly, though not exclusively, on developments in the US and the UK. In line with perspectives published in 2010 as Big Potatoes: The London Manifesto for Innovation, the paper is critical of DT, arguing that it acts as a force broadly hostile to technological innovation. ${ }^{6}$ As well, the paper looks at the roots of DT today, and, in its conclusion, begins to outline an alternative approach.

\section{Justifying the Term 'Craze'}

Sixty years ago, the industrial designer Raymond Loewy's success with clients granted him the cover of Time magazine. ${ }^{7}$ Today, many more designers have become celebrities; but celebrated, too, is the reputed superiority of design thinking over conventional management theory and practice.

The rise of DT fully allows use of the term 'craze'. Chronicling that rise in 2009, Brigham Young University's Paul Skaggs and others described DT as 'one of the hottest topics in the business arena in recent years'. It had ascended to top international universities. It had appeared in Daniel Pink's 2005 book A Whole New Mind. DT had been a theme at the 2006 World Economic Forum. ${ }^{8}$

DT first won friends in education and business in 2005, when the Hasso-Plattner-Institute at Stanford University began teaching it. ${ }^{9}$ It entered the mainstream of US management literature when Tim Brown, CEO of the design consultants IDEO, advocated it in the Harvard Business Review in 2008. ${ }^{10}$ Then, in 2010, The Economist newspaper held a major business conference on DT in London, and it was reported that DT had reached China, India, Mexico, and Brazil. ${ }^{11}$ In 2011, Amazon.co.uk listed more than a dozen books, recently or shortly to be published, with the phrase 'design thinking' in their titles. ${ }^{12}$

\footnotetext{
${ }^{6}$ See Big Potatoes: The London Manifesto for Innovation, Thinking Apart, October 2010, on www.BigPotatoes.org. I am a co-author of this manifesto.

${ }^{7}$ See Time, 31 October 1949.

${ }^{8}$ Paul Skaggs and others, 'Thinking about Design Thinking', paper given to the 13th Annual Meeting of the National Collegiate Inventors and Innovators Alliance (US), 19-21 March 2009, on http://nciia.org/conf09/papers/Skaggs.pdf. In fact Daniel Pink's book does not refer to DT by name, but commended design for many of the attributes that today are associated with DT.

${ }^{9}$ Later, DT began to be taught at the Hasso-Plattner-Institute for IT Systems Engineering in Potsdam, Germany. See Hasso Plattner, 'Foreword', in Christoph Meinel, Larry Leifer and Hasso Plattner, Design Thinking: Understand - Improve - Apply, Springer, 2011, page v. Hasso Plattner is a co-founder of the German software multinational SAP.

${ }^{10}$ Tim Brown, 'Design thinking', Harvard Business Review, June 2008.

${ }^{11}$ On the Economist conference, see Kevin McCullagh, 'Design thinking: everywhere and nowhere', Core 77, 29 March 2010, on http://www.core77.com/blog/columns/design_thinking_a_useful_myth_16790.asp, On the export of DT beyond the US, see Bruce Nussbaum, 'China, India, Mexico, and Brazil embrace "Design Thinking"“, Co. Design, 21 September 2010, on http:/www.fastcodesign.com/1662340/what-are-the-best-design-thinking-consultancies-in-china-india-mexico-and-brazil. Also in 2010, the US journalist and author Warren Berger managed to publish a book on design first without, then with the phrase 'design thinking' in its title - a remarkable feat. In the UK, Random House published Berger's Glimmer: How Design can Transform your Business, your Life, and Maybe even the World on 7 January 2010. Penguin published the same book, titled CAD Monkeys, Dinosaur Babies, and T-Shaped People: Inside the World of Design Thinking and How It Can Spark Creativity and Innovation, on 26 December 2010.

${ }^{12}$ Accessed 4 March 2011.
} 
The frenzy about DT today stands in marked contrast to the gradual but gathering stagnation of Western R\&D over the past 50 years, a stagnation that is documented elsewhere. ${ }^{13}$ But in fact the contrast is just the point. Sometimes explicitly, DT counterposes itself to technological innovation, intimating that faith in technology is just a bit out of date. Altogether, then, a 'modernising' but low-risk, technology-lite DT may be both a product and a reinforcer of the West's diminishing interest in and passion for investment in technological innovation. Indeed, DT may be product and part-producer of what the author Daniel Ben-Ami has described as growth scepticism - broadly, doubt and suspicion about economic growth. ${ }^{14}$

There is a second reason why a craze today surrounds DT. Especially since the end of the Cold War (1989-91), Western elites have had to work hard to maintain their political legitimacy - and, in a modest but noticeable way, DT could come in handy in that work. Because DT advocates the participation of the users of design, and particularly the participation of users of services, it can appear to some as a useful means of legitimation - democratic, bottom-up, a world apart from the stuffy laboratory of old. Here DT can once again, and perhaps inadvertently, encourage a casual attitude to the practice of science and technology.

Despite the craze for DT having these important and rather contemporary roots, DT itself has a long lineage, even if people have not used the term for very long.

Old perceptions of design based on the individual, craftsman-like designer first began to be jettisoned in September 1962, with a London conference on what was then called Design Methods. ${ }^{15}$ In the UK and also the US, theorists of design and innovation began to favour both the role of science and technology 'push', and a broader, more systematic vision of design that included 'demand pull', and an orientation toward users and their needs.

Space here does not allow a review of the successes and failures of Design Methods. ${ }^{16}$ Nor is this the place to review how environmentalism, given its founding text by Rachel Carson in 1962, established a position for itself in design with Ernst Schumacher's and Victor Papanek's support for low-technology products and systems in the Third World. ${ }^{17}$ Yet it is notable how, from the early 1970s onward, there proved to be little relationship between Design Methods and environmentally minded design.

\footnotetext{
${ }^{13}$ See for example Big Potatoes, op cit. See also Michael Mandel, 'The failed promise of innovation in the US', cover story, Bloomberg Business Week, 3 June 2009, on http://www.businessweek.com/magazine/content/09_24/ b4135000953288.htm?chan=magazine+channel_top+stories; 'Big Think interview with Peter Thiel', Big Think, 21 November 2010, on http://bigthink.com/ideas/25082, and Tyler Cowen, The Great Stagnation: How America Ate All The Low-Hanging Fruit of Modern History, Got Sick, and Will (Eventually) Feel Better, Penguin, only purchasable as an e-book on http://www.amazon.com/Great-Stagnation-Low-Hanging-Eventually-ebook/dp/ B004H0M8QS

${ }^{14}$ Daniel Ben-Ami, Ferraris for All: In Defence of Economic Progress, Policy Press, 2010.

15 The conference was held at the department of aeronautics at Imperial College, London. John Christopher Jones, one of the organisers, gives a list of other organisers and a list of participants, complete with short quotations from many of those who attended, on his website. See 'Anniversary!', 19 September 2002, on http://www.softopia.demon.co.uk/2.2/dmconference1962.html. After further conferences, the Design Methods movement led to the formation of the Design Research Society in 1967, and the publication of the journal Design Studies.

${ }^{16}$ An enormous body of writing surrounds Design Methods. Its history, and the problematic relationship design methodology has had with science, are treated by Nigel Cross, 'Science and design methodology: a review', Research in Engineering Design, Vol 5, No 2, 1993. See also Cross, 'Forty years of design research', Design Research Quarterly, Vol 1, No 2, December 2006/January 2007, on http://www.drsq.org/issues/drq2-1.pdf.

${ }^{17}$ For a treatment of Schumacher and Papanek, see James Woudhuysen and Joe Kaplinsky, Energise! A Future for Energy Innovation, Beautiful Books, 2009, pp86-7, 452-454. Importantly, in 1965 Schumacher co-founded the Intermediate Technology Group, now known as the Third World charity Practical Action: see http://practicalaction.org/about-us/history.
} 


\section{After 1957: The Birth of Design Methods and the Idea of 'Wicked' Problems}

If DT's intellectual antecedents begin with the early 1960s, it gained a boost in the years before and - especially - after the end of the Cold War. It is worth comparing the two eras.

After the soul-searching in America that accompanied the launch of Sputnik in 1957, there was both revived interest in scientific and technological innovation, and also dissent from the imperious ideas about innovation and consumption that large companies loved. In 1958 John Kenneth Galbraith published The Affluent Society, attacking the corporate manipulation of consumers. In 1960 Vance Packard did much the same around advertising (The Hidden Persuaders) and what he christened 'planned obsolescence' - the phrase is his (see The Wastemakers). In her famous book The Feminine Mystique (1963), Betty Friedan denounced magazines for creating an image of housework that required 'increasing mindlessness, increasing emphasis on things: two cars, two TVs, two fireplaces'. ${ }^{18}$ Meanwhile, following Thomas Kuhn's The Structure of Scientific Revolutions in 1962, even science came to be seen as a bit of a conspiracy; not as the march of progress, but rather as a clash between different but confidently-held ideological frameworks ('paradigms', as Kuhn put it).

At the height of the Cold War, scepticism about science, technology, consumption and economic growth was only beginning to make itself felt. But with the birth of that scepticism there was also concern to uphold the autonomy of product users, and to distinguish their real needs from those dreamt up by companies. The Design Methods movement absorbed this concern, even if it was optimistic about technology in general, and about IT in particular. ${ }^{19}$

A little later, systematic approaches to design took a fresh turn in the category of 'wicked' problems proposed by Horst Rittel, a mathematician, designer, once a teacher at the Hochschule für Gestaltung at Ulm, Germany, and later a professor at the University of California, Berkeley. As the operations research expert Charles West Churchman, also at Berkeley, succinctly described them in 1967, Rittel's wicked problems comprised 'that class of social system problems which are ill-formulated, where the information is confusing'. With wicked problems, Churchman added, operations research and management science had a moral problem, especially when they pretended to have solved wicked problems completely. ${ }^{20}$ This was a doctrine that proved useful in the second era we have mentioned, in which the phrase 'design thinking' first emerged.

\section{Around Cold War's End: The Elevation and Blurring of Design's Role}

Toward and after the end of the Cold War, the need to attend to what markets want, rather than to what corporate or societal leaders insist on, became a mantra - and 'bottom up', demand-driven interpretations of management, innovation and design gained new adherents. In 1984, Tom Peters and Robert J Waterman Jnr's In Search of Excellence had issued a battle cry on the need to be 'close to the customer'. In the following year, Peter Drucker suggested

\footnotetext{
${ }_{18}^{18}$ Betty Friedan, The Feminine Mystique (1963), Pelican, 1983, p58.

${ }^{19}$ Typical of the new sensitivity to users was the career of Brian Shackel (1927-2007), later the doyen of ergonomics in Britain. In 1962, Shackel introduced a pioneering redesign of a computer console for EMI Electronics.

${ }^{20}$ C West Churchman, 'Wicked problems', Guest Editorial, Management Science, Vol 14, No 4, December 1967, pp B141-B142. 'Deception', Churchman presciently wrote, 'becomes an especially strong moral issue when one deceives people into thinking that something is safe when it is highly dangerous.' Ibid.
} 
in a seminal article that innovation orientated to demographic change was 'very reliable', but that, by contrast, the pursuit of knowledge-based innovations had its 'dangers'. On top of knowledge in innovation, careful analysis of the needs - and above all the capabilities of the intended user, Drucker admonished, was 'also essential'. ${ }^{21}$

Despite the can-do ethos of the 1980s in the US, Drucker was not alone in highlighting the risks that attend the pursuit of technological innovation. In 1986, the year of the Chernobyl nuclear disaster in Ukraine, Ulrich Beck's Risk Society suggested that technological change could bring unpredictable catastrophes. In 1987, the American journalist James Gleick's bestseller Chaos spread the idea that physical changes are, by their nature, impossible to pin down. In 1988, Margaret Thatcher acclaimed the benefits of basic, curiosity-driven research, but also espoused the concept of sustainable economic development, citing, among other things, fears 'that we are creating a global heat trap which could lead to climatic instability'. ${ }^{22}$ That same year, the Danish architect and designer Niels Peter Flint founded the O2 International network of designers orientated to environmentalism; ${ }^{23}$ and around the same time, the United Nations Intergovernmental Panel on Climate Change was formed.

Thinking about design reflected this kind of context. In 1987, Harvard professor of architecture and urban design Peter Rowe, analysing what he called 'the interior situational logic and the decision-making processes of designers in action' around his subject fields, used philosophy, logic and typology to outline several very different ways in which designers think. Printed seven times by 1998, Rowe's book Design Thinking paid little attention to the role of technology in the work of designers, but concluded with an attack on 'reductionist and naïve functionalism' in design and the way it was so often 'determined by a "scientific view" of man and his world'. In his final remarks, Rowe tartly observed that there was 'growing suspicion of the kind of "liberal faith" implicit in the role of urban theorists and practitioners as aloof observers and dispensers of information and technical know-how' ${ }^{24}$

In such a framework, remote or 'aloof' designers were urged to play down scientific and technical know-how. Instead, inspired by the speed of new product development ('time to market') boasted by Japanese manufacturers of cars and consumer electronics, the consensus in US managerial circles moved toward favouring the designer's participation in multidisciplinary project teams, the better to overcome 'silo' department walls within the firm. ${ }^{25}$

The trend toward a more horizontal organisation of innovation was not new. ${ }^{26}$ Nor were teams without merit: as late as 1993, Jon Katzenbach and Douglas Smith could still make a rational division of labour, or what they called the 'complementary skills' of individuals, one of their arguments in favour of teams. ${ }^{27}$ However in the post-Cold War era the role

\footnotetext{
${ }^{21}$ Drucker, 'The discipline of innovation', Harvard Business Review, May-June 1985, pp70, 71.

${ }^{22}$ Margaret Thatcher, speech to the Royal Society, 27 September 1988, on www.margaretthatcher.org/speeches/displaydocument.asp?docid $=107346$

${ }^{23}$ Aided by Dutch designers, the network held its first major international conference in 1993. See Barbara Kiser, 'A blast of fresh air: the history of O2', 2000, on http://www.o2.org/media/document/Kiser.pdf

${ }^{24}$ Peter G Rowe, Design Thinking, The MIT Press, 1987, pp199. Rowe's point about the aloofness of urbanists drew upon Donald Schon's The Reflective Practitioner: How Professionals Think in Action (1984).

${ }^{25}$ Kim B Clark and Takahiro Fujimoto, 'The power of product integrity', Harvard Business Review, NovemberDecember 1990. See also Clark and Fujimoto, Product Development Performance: Strategy, Organization, and Management in the World Auto Industry, Harvard Business Press, 1991.

${ }^{26}$ See Alvin Toffler, chapter 7, Future Shock (1970), Bantam, 1984.

27 Jon Katzenbach and Douglas Smith, The Wisdom of Teams: Creating the High-performance Organization, Harvard Business School Press, 1993.
} 
generally held out for teams became more and more clouded. Teams were variously lauded as egalitarian, loving and playful. ${ }^{28}$ Indeed, quite recently, the Harvard Business Review felt moved to complain that, over two decades, a 'cult' had grown up around teams, which were now 'considered almost sacrosanct." 29

For designers, rhapsodies for teams brought important benefits. First, the role of designers became more elevated - and, as Tom Peters made clear in the very first issue of the Design Management Journal, could now embrace the world of services, not just of artefacts. ${ }^{30}$ Second, as Monitor's article more recently confirms, designers scored points by claiming their affinity to user-orientated anthropologists, ethnographers and psychologists. ${ }^{31}$ Third, like the team itself, the role of designers became more blurred. Finally, within teams, the role of technologists became less distinct.

In the years after the Cold War, when the threat to capitalism from the Soviet Union had clearly ended, the legitimacy of establishment institutions eroded. Meanwhile, environmentalists built new critiques of growth, and especially of energy technologies. Then, in a major 1992 article on the merits of design thinking, Richard Buchanan, professor of design, management and information systems at Case Western Reserve University, Cleveland, fashionably took his distance from traditional expertise, and in particular from that held by technologists. Here, like Rowe, Buchanan drew upon Horst Rittel, titling his article 'Wicked problems in Design Thinking, ${ }^{32}$

Following Rittel, Buchanan opposed the 'linear' model of design, in which, on any project, an analytical phase of problem definition is followed by a synthetic phase of problem solution. Buchanan wrote:

'The linear model of design thinking is based on determinate problems which have definite conditions.... By contrast, the wicked-problems approach suggests that there is a fundamental indeterminacy in all but the most trivial design problems.... there are no definitive conditions or limits to design problems'.33

Designers, Buchanan argued, held many philosophies of design, which did not and could constitute a science of design in the sense of any natural, social, or humanistic science. Why? Because design was 'fundamentally concerned with the particular, and there is no science of the particular. ${ }^{34}$

If the Design Methods movement had been overly and somewhat narrowly concerned with a systems view of design, Buchanan made DT so powerful as to embrace everything everything, that is, except technological innovation. Buchanan was anxious to say that, while

\footnotetext{
${ }^{28}$ See James Woudhuysen and Ian Abley, Why is Construction so Backward?, Wiley, 2004, p48, and Woudhuysen, 'Play as the main event in international and UK culture, Cultural Trends, Issues $43 \& 44,2003$, Policy Studies Institute, pp139-142, on www.psi.org.uk/docs/2003/news-CT-Woudhuysen-play.pdf

29 'Why teams don't work', interview with Harvard professor of social and organisational psychology L Richard Hackman, Harvard Business Review, May 1999, p99.

${ }^{30}$ See Peters, 'The Design Challenge', Design Management Journal, Vol 1, No 1, Fall 1989, p4.

${ }^{31}$ By 1997, ethnography - properly defined as the detailed description of the culture of a particular society based on fieldwork and participation in the life of the society - was a discipline claimed to be one of the approaches used by every major design firm in the US. Christina Wasson, 'Ethnography in the field of design', Human Organisation, Vol 59, No 4, 2000, quoted in Department of Trade and Industry, Innovation through People- centred DesignLessons from the USA, Global Watch Mission Report, October 2004, p14.

32 Richard Buchanan, 'Wicked problems in Design Thinking', Design Issues, Vol VIII, No 2, Spring 1992, pp6, 9-10, 16 .

33 Ibid, pp15-16.

${ }^{34}$ Ibid, p17.
} 
'most people' regarded technology as things or machines, design was in fact restoring something richer in meaning to the term, namely that technology was 'a discipline of systematic thinking, 35

Here, like it or not, the role of the designer was not really to humanise technology, as for many years it had been - still less to spur technologists to further heights of achievement. Rather, the role of basic scientific research and technological development was fundamentally obscured, while DT came out smelling of roses. For Buchanan, DT could be 'applied to any area of human experience' because it had 'no special subject matter of its own apart from what a designer conceives it to be'. ${ }^{36}$

This conception of DT betrayed a relativism that recalled some of the more ardent followers of Thomas Kuhn in the 1960s. It was also a conception of DT as arbitrary as post-Cold War international relations. Ironically, however, the spread of mobile phones and the Internet, and the growth of the projects that surrounded this, continued to make users, not technology, more prominent in the world of design.

In some hands, notably those of Bill Moggridge, the founder of design consultants IDEO and of the discipline known as interaction design, the interfaces surrounding IT-based products and services perceptibly improved. Moreover in 1994, Nokia's 2110 handset ushered in the mobile phone not just as a well-designed modern consumer device, but also as an overdue emblem of user-centred design. ${ }^{37}$ Elsewhere, however, design came to anticipate and absorb, all too quickly and uncritically, doctrines of emotional intelligence and the experience economy. 38

The tilt away from technology was subtle, but significant. The appointment of Milanese designer Stefan Marzano as head of design at Philips signaled a departure from the Dutch firm's old, functional approach to product design. The expressive merits of the revamped VW Beetle (1993) won plaudits, as did 'Anna G' (1994), a corkscrew that, designed by Alessandro Mendini for Alessi, was shaped like a happy woman. The launch of the Apple iMac in 1998 confirmed the trend toward playful products. ${ }^{39}$

By the 1990s, then, there was growing confidence in and scope for design and DT - just when, as a fraction of GDP, Western expenditures on R\&D by business and by government stagnated. $^{40}$ Meanwhile, denied the traction once had in the fight against communism, Western elites found themselves less legitimate, more subject to popular disapproval, and more confronted - from the Middle East to Yugoslavia - with what they regarded as 'wicked' problems. Thus, apart from the important, low-carbon exception of IT, the prestige of tech-

\footnotetext{
35 Ibid, p19.

${ }^{36}$ Ibid, pp16, 18-19.

${ }^{37}$ In words that perhaps haunt the company today, Nokia CEO Jorma Ollila laid some stress on the need to understand consumer behaviour, and the need to 'serve our customers'. Ollila, 'Review by the President and CEO: A year of growth, change and challenges’, in Nokia, Annual Report 1995, 1996, p7, on http://web.lib.hse.fi/FI/ yrityspalvelin/pdf/1995/enokia.pdf

38 The key texts here are Peter Senge, The Fifth Discipline: the Art and Practice of the Learning Organisation, Bantam/Dell, 1990; Daniel Goleman, Emotional Intelligence, Bantam, 1995; B Joseph Pine II and James H Gilmore, 'How to profit from experience', Wall Street Journal, 4 August 1997, and, more famously, Pine and Gilmore, The Experience Economy: Work is Theatre \& Every Business a Stage, Harvard Business School Press, 1999.

39 The following year, the international Design \& Emotion society held its first conference in Delft, the Netherlands, concentrating on experience design. See www.designandemotion.org

${ }^{40}$ See Organization for Economic Cooperation and Development, Sample table and charts, Main Science and Technology Indicators (MSTI): 2010-1, 30 June 2010, p21, on http://www.oecd.org/dataoecd/9/44/41850733.pdf
} 
nology fell, while that of design, and the range of problems it thought it could deal with, expanded. In fact, while the market-based triumphalism of the West immediately after its victory in the Cold War was dissipated soon enough, triumphalist feeling among designers tended to grow.

\section{The Mid 2000s: of Happiness, Services, Nature - and Workplace Design}

In understanding the climacteric for DT of the mid 2000s, the career of Donald Norman, an American cognitive scientist and engineer, is relevant. In 1988, Norman's The Psychology of Everyday Things became a bible of user centred design and interaction design. Then, in 2004, Norman's Emotional Design became required reading. At this stage, Norman held that engineers and designers knew too much about technology, and too little about how other people lived their lives. ${ }^{41}$ For him, as for others later, the aesthetics of design were now key, and helped create among users 'positive feelings such as love, attachment, and happiness'. 42

In Britain, the state was already interested in happiness - and today all its departments take it into account. ${ }^{43}$ As a result, the Treasury's Budget 2005 not only discussed happiness, but portrayed a major aspect of DT as vital to that goal. For the Treasury, satisfaction with public services meant that both their users and public sector staff had to be 'fully engaged' in their design and delivery. There had to be 'more opportunities for users to participate in the design, delivery and governance of public services'. 44

In a quest to be popular and legitimate, the British government expanded the role for design. At the same time, though, civil servants narrowed the scope for technology. Following the Avoiding Dangerous Climate Change conference of February 2005, it was sustainable, low-carbon and energy-saving technologies that dominated the ways in which Budget 2005 talked about technology.

Thinking about design reflected the new, decidedly low-tech preoccupations. Design, it had previously been argued, should be inspired by nature. ${ }^{45}$ Now, in the wake of the internationally acclaimed Stern report on climate change, ${ }^{46}$ books on Green design multiplied. In addition, the idea blossomed that thinking and practice in design should be ethical. ${ }^{47}$ Last,

\footnotetext{
${ }^{41}$ Donald Norman, Emotional Design: Why We Love (or Hate) Everyday Things, Basic Books, 2004, p81.

${ }^{42}$ Ibid, p7. On the pay-off with aesthetics, see Virginia Postrel, The Substance of Style: How the Rise of Aesthetic Value is Remaking Commerce, Culture, and Consciousness, HarperCollins, 2003, and Gerhard M Buurman, ed, 'Foreword', Total Interaction: Theory and Practice of a New Paradigm for the Design Disciplines, Birkhäuser, 2006. For reviews of these two books, see James Woudhuysen, 'Who's afraid of Virginia Postrel?', Blueprint, April 2005, on http://www.woudhuysen.com/documents/PostrelBLUEPRINT.doc, and 'Interaction design and the failure of post-modernism', Woudhuysen.com, 2 August 2007, on http://www.woudhuysen.com/index.php/main/article/ 189

${ }^{43}$ For the early interest, see Cabinet Office Strategy Unit, Seminar on Life Satisfaction, 4 November 2002.

${ }^{44}$ HM Treasury, Investing for our future: Fairness and Opportunity for Britain's Hard-working Families. Economic and Fiscal Strategy Report and Financial Statement and Budget Report, March 2005, p144, on http://www.archive2.official-documents.co.uk/document/deps/hc/hc372/372.pdf

45 Janine Benyus, Biomimicry: Innovation Inspired by Nature, William Morrow, 1997; Paul Hawken, Amory B Lovins and L Hunter Lovins, Biomimicry: Innovation Inspired by Nature, (1999), Earthscan, 2000, revised edition, pp14-16, 73 .

${ }^{46}$ See Lord Nicholas Stern, Stern Review on the Economics of Climate Change, HM Treasury, 2006, on www.hmtreasury.gov.uk./independent_reviews/stern_review_economics_climate_change/stern_review_report.cfm

${ }^{47}$ See for example Clare Dowdy, 'Virtuous circles', Design Week, 21 September 2006, and the work of the Ethical Design Collective, on http://www.ethicaldesign.co.uk
} 
the role of workplaces was reconceived. Instead of workplaces and the technology within them being seen as key to productivity and the creation of wealth, the design of workplaces came to be seen as a key factor in... the health or 'wellness' of employees, and in the interactivity and creativity of employees. ${ }^{48}$

From IDEO, chief executive Tim Brown's 2009 bestseller on DT, Change by Design, gathered together all the themes we have mentioned. ${ }^{49}$

\section{The Gospel of DT Today}

In loose-limbed, witty and urbane prose, Change by Design has created an alluring and apparently seamless body of ideas about DT. It is, the book says, a three-stage process of inspiration, ideation and implementation, although this sequence of actions must needs be iterative. ${ }^{50}$ In a critique of the 'linear' approach from which Richard Buchanan had earlier differed, the book calls for a 'continuous movement between divergent and convergent processes, on the one hand, and between the analytical and the synthetic, on the other'. 51 Teams must be 'smart', and not multidisciplinary (the individual member as advocate for his or her discipline), but interdisciplinary (collective ownership of and responsibility for ideas). ${ }^{52}$ Along with interaction design and experience design, services, not just artefacts, are a key arena for DT. Just as designers are now following biomimicry, so organisations should mimic the ecosystems of nature and go about harvesting ideas. ${ }^{53}$ Special kinds of workplace designs make for creativity. ${ }^{54}$

There is much to recommend in Change by Design. ${ }^{55}$ Like Big Potatoes, the author enjoins his readers to Think Big, and is a strong advocate of prototyping and - in one passage technological experiments. ${ }^{56}$ Yet the fact is that, for a book properly wedded to the analytical aspects of DT, assertions beat analysis in Change by Design - particularly, assertions about the defects of technology. Technology and industrialisation have not only created climate change; they have fed into 'a culture of excess consumption and prodigious waste'. 57 Achievements in, say, biotechnology and nanotechnology are 'unlikely to help us reverse our ominous course. Just the opposite'. ${ }^{58}$ The book continues:

\footnotetext{
48 James Woudhuysen and Ian Abley, Why is Construction so Backward?, op cit, pp49, 84.

49 Tim Brown, Change by Design: How Design Thinking Transforms Organizations and Inspires Innovation, HarperBusiness, 2009.

${ }^{50}$ Ibid, p16.

51 Ibid, p70.

52 Ibid, pp27-28.

53 Ibid, pp73-74.

${ }^{54}$ Ibid, pp31-36.

55 Rightly, if revealingly, the book notes that 'a striking development of recent years has been the migration of designers toward social behavioral problems, such as adhering to a drug regimen or shifting from junk food to healthy snacking'. The book is also right that design needs to think not just about individuals, but also about how groups interact with each other. Ibid, pp42, 56.

${ }_{56}$ Here the book has the good manners to select Chuck House, the Hewlett-Packard engineer who illicitly developed, in the 1960s, a large-screen cathode ray tube which went on to be the world's first commercially successful computer graphics display. Ibid, pp71-72. Change by Design also rightly cheers on innovations that create both new products and new users or markets, and rightly, too, warns that companies suspending innovation during an economic downturn 'will only weaken it'. Ibid, pp163, 175.

${ }^{57}$ Ibid, p2. Elsewhere, Change by Design feels called upon to assert: 'we are entering an era of limits; the cycle of mass production and mindless consumption that defined the industrial age is no longer sustainable'. Ibid, p178.

${ }^{58}$ Ibid, p3.
} 
'A purely technocentric view of innovation is less sustainable now than ever.... What we need are... new products that balance the needs of individuals and of society as a whole; new ideas that tackle the global challenges of health, poverty, and education; new strategies that result in... a sense of purpose that engages everyone affected by them... an approach to innovation that is... broadly accessible, that can be integrated into all aspects of business and society. ${ }^{59}$

This may be a moral stance, even an ethical one. But clearly social inclusion has won out, again, against technological innovation. Predictably, Change goes on to invoke Peter Drucker and repeat that 'reliance on technology is hugely risky'. ${ }^{60}$ Instead, it urges employers to 'engage a far greater percentage of their workforce' in DT. ${ }^{61}$

The central and conservative logic of the book emerges early. Rightly invoking the designer Charles Eames and his and portrait of design as 'a willing embrace of constraints', Change wrongly puts forward a highly constrained agenda. DT, it says, is about bringing into harmonious balance the human desirability of products and services with technological feasibility ('what is functionally possible within the foreseeable future') and economic viability ('what is likely to become part of a sustainable business model'). ${ }^{62}$

The latter two categories cannot go unquestioned. For what is technologically feasible cannot be predicted in advance of a project, and, even within one, partly depends on the scale of economic investment. And that, like economic viability, is partly a political question. Many things can turn out to be viable and sustainable if people decide that they are.

Change makes it clear, however, that $D T$ is the means for resolving what would otherwise be understood as technological, economic and political problems. As a result, though technology has its limits, DT does not. 'There will always be a place in our dizzying world for the artist, the craftsman, and the lone inventor', the book winningly concedes, but the next generation of designers 'will need to begin looking at every problem - from adult illiteracy to global warming - as a design problem'. ${ }^{6}$

In much of Change there is ridicule for technology, and triumphalism about design. We are also told that insight into consumers, who are seen more as needy than they are as possessors of talents, 'does not usually come from reams of quantitative data ${ }^{\text {,6 }}$ - although in fact in 2011 it remains indisputable that both technological and also market insights do come from such data. Again, 'a sole reliance on technical prowess is less effective in today's market than it once was'. And while small companies might be good at technological innovation, 'large companies are better positioned to look for breakthroughs from within their existing markets, where technical virtuosity provides no assurance of success' ${ }^{65}$

The preference for popular participation rather than new technology is clear in the fondness for storytelling, a practice that may have its place in design and innovation today, but has

\footnotetext{
${ }^{59}$ Ibid.

${ }^{60}$ Ibid, p20.

${ }^{61}$ Ibid, p165.

${ }^{62}$ Ibid, pp4, 17-20.

63 Ibid, p38.

${ }^{64}$ Ibid, pp40-41.

${ }^{65}$ Ibid, pp158, 159.
} 
elsewhere rightly been castigated for its role, with governments and employers, in reconciling people to the status quo. ${ }^{66}$ Change says:

'Many notions have been proposed to explain what differentiates human beings from other species: bipedal locomotion, tool use, language, symbolic systems. Our ability to tell stories also sets us apart'. ${ }^{\text {, }}$

Well, yes. But missing here is any suggestion - beyond 'tool use' - that humanity is distinguished by its progress from the mire, a progress aided, though obviously not exclusively, by technological innovation. Similarly, in one of the many outings for health care in Change by Design, DT is held out as a means of thinking of patients as people who can 'help write their own stories'. ${ }^{6}$

Perhaps. But patients might value more highly a breakthrough in cancer research, and its subsequent technological application in new remedies. Yes, the pharmaceutical industry needs, still, to learn a lot about design, its methods and the end-users of the industry's products: patients with high blood pressure, for example, are estimated to take only 53-70 per cent of the medication prescribed for them. ${ }^{69}$ However in the case of hypertension, poor patient 'adherence' probably grows out of beliefs about illness and treatment; out of unpleasant side effects, and out of the complexity of treatment regimes. It seems that advances in the perception, effectiveness and simplicity of scientific and technological innovation will do more for patients than better packaging and instruction design.

\section{Toward an Alternative to DT}

Change by Design is not the last word on DT. ${ }^{70}$ Nevertheless as the designer Kevin McCullagh has noted, some managers, especially in government, have adopted DT rather uncritically. By contrast, in design circles defenders of DT have prompted a schism there. ${ }^{71}$ It is a schism as grand, perhaps, as that between post-Modernism and Modernism back in the 1970s/1980s.

McCullagh is not alone in stating that DT has wrongly made consumer contexts, behaviours and needs seem preferable to 'other drivers of innovation, including technical progress' ${ }^{72}$ In a major turn away from his earlier trajectory, Donald Norman has attacked DT as 'a public relations term for good, old-fashioned creative thinking... [that is] not restricted to designers'. ${ }^{73}$ Commendably, Norman has also upheld the banner of science for designers,

\footnotetext{
${ }^{66}$ See Christian Salmon, Storytelling: Bewitching the Modern Mind, Verso, 2010. For a review of this book, see James Woudhuysen, 'An engaging tale, packed with myths', spiked review of books, May 2010, on http://www.spiked-online.com/index.php/site/reviewofbooks_article/8938.

${ }^{67}$ Brown, Change by Design, op cit, pp131-2.

${ }^{68}$ Ibid, p136.

${ }^{69}$ Cited in F Alhalaiqa and others, 'Adherence therapy for medication non-compliant patients with hypertension: a randomised controlled trial', Journal of Human Hypertension, 17 February 2011, on http://www.nature.com/jhh/journal/vaop/ncurrent/pdf/jhh2010133a.pdf

70 Space does not permit a treatment here of Roger Martin, The Design of Business: Why Design Thinking is the Next Competitive Advantage, Harvard Business Press, 2009, and Martin, 'What is Design Thinking anyway?', Observatory, 28 September 2009, on http://observatory.designobserver.com/entry.html?entry=11097. See also Thomas Lockwood, editor, Design Thinking: Integrating Innovation, Customer Experience, and Brand Value, Allworth Publishing, 2009.

${ }^{71}$ Kevin McCullagh, 'Stepping up: design thinking has uncovered real opportunities', DMI Review, 29 September 2010, on http://www.plan.bz/docs/steppingup_0.pdf

72 Ibid.

73 Don Norman, 'Design thinking: a useful myth', Core 77, 25 June 2010, on
} 
accusing them of being, on the whole, 'quite ignorant of all this science stuff', ${ }^{74}$ At the US design consultancy Adaptive Path, Peter Merholz has also been very scathing:

'We have librarians, and historians, and fine artists. All of these disciplinary backgrounds allow... for insights that wouldn't be achieved if we were all cut from the same cloth. Do we need to espouse "library thinking", "history thinking", and "arts thinking?" 75

Last, Robert Verganti, professor of management of innovation at Politecnico di Miliano has, in refreshing style, criticised DT for neglecting not just technological innovation, but also the meaning that design confers on products. ${ }^{76}$

Meanings are indeed important to design. ${ }^{77}$ An alternative to DT, then, must look carefully at what products and services connote.

A second merit of Verganti is that he takes seriously an aspect of products and services about which Brown is silent, and about which another, more popular but equally useful primer on DT, is almost silent: cost. ${ }^{78}$ In the DT universe, costs and economics never get a chapter of their own. ${ }^{79}$ So secondly, any alternative to DT must interrogate costs.

Third, in DT 'sustainability' tends to be taken for granted. ${ }^{80}$ There is no link drawn between the user's perspective, the environmental perspective, and the price of goods in the shops. Given that consumers tend to put price questions above environmental ones, and that an inflationary world has made them more price-conscious, this is an unpardonable omission. So an alternative to DT must also interrogate sustainability. With Change by Design, for instance, the book is more interested in energy conservation than in the generation of new energy - a debatable point of view.

Fourth, design could do with a forward-looking perspective. Design needs to be able to collect and suspect the projections made by other disciplines of society and of the meanings to come; of economics and costs, and of the environment. An alternative to DT, then, must deal with, in a critical style and using all the data that is relevant, forecasts of the future.

http://www.core77.com/blog/columns/design_thinking_a_useful_myth_16790.asp

${ }^{74}$ Don Norman, 'Why design education must change', 26 November 2010 , Core 77, on

http://www.core77.com/blog/columns/why_design_education_must_change_17993.asp

${ }^{75}$ Peter Merholz, 'Why Design Thinking won't save you', Harvard Business Review blogs, 9 October 2009, on http://blogs.hbr.org/merholz/2009/10/why-design-thinking-wont-save.html

${ }_{76}$ Roberto Verganti, Design-driven Innovation: Changing the Rules of Competition by Radically Innovating what Things Mean, Harvard Business School Press, 2009, and Verganti 'One size does not fit all in innovation (and never will)', Harvard Business Review Blogs: The conversation, 19 April 2010, on

http://blogs.hbr.org/cs/2010/04/one_size_does_not_fit_all_in_i.html.

${ }_{77}$ Quarrels may be had with Verganti on the merits of different meanings - he praises Alessi's products for 'talking to our inner child', despite the fact that the Alessi product favoured by Verganti and already mentioned in this paper, the corkscrew Anna G, proves in practice to be very poor in balancing a childish exterior with the functional ability actually to open bottles of wine. Verganti, Design-driven Innovation, ibid, pp7, 40-42.

${ }^{78}$ See Gavin Ambrose and Paul Harris, Basics Design: Design Thinking, Ava Publishing, 2009. This book is notable for following its main text on DT with a short homily on the importance of ethics.

${ }^{79}$ Roger Martin does consider costs, but gives them no dedicated treatment. Still, at the Service Design Symposium in Copenhagen, 1 July 2008, Mikkel Rasmussen of ReD Associates pointed out how weak designers are on economics, and how service design must provide value for money. See Rasmussen, 'Mikkel Rasmussen on Service Design', parts 1 and 2, on http://www.youtube.

com/watch?v=Q6dYuOxKiJo and http://www.youtube.com/watch? $\mathrm{v}=00 \mathrm{cmr}-\mathrm{XN} 7 \mathrm{~ns} \& \mathrm{NR}=1$.

${ }^{80}$ Upholding sustainability, Roberto Verganti has nevertheless pointed out the major differences that exist between sustainability and user-centered innovation. See Verganti, 'User-centered innovation is not sustainable', Harvard Business Review Blogs: The conversation, 19 March 2010, on http://blogs.hbr.org/cs/2010/04/one_size_does_not_fit_all_in_i.html. 
Finally an alternative to DT must eschew triumphalism, and make sure that designers have a bit of humility in their dealings with scientific and technological innovation. ${ }^{81}$

So is DT, in today's practice of it, really just a complement to, not a substitute for, R\&D? The evidence presented here suggests that DT is pursued with a zeal that can only detract from the more vigorous pursuit of R\&D. And are DT's claims to facilitate the participation of stakeholders of all descriptions to be taken at face value? Again, the evidence suggests otherwise. The legitimation of corporate and official bodies and the de-legitimation of those stakeholders known as scientists and technologists seem to be the main results of DT.

Today, investment inertia and political distrust surround science and technology in the West. Often, these things are seen as too expensive, slow or risky to be worthwhile. Yet the fact is that major scientific and technological innovations have benefited mankind much more than innovations in design. Likewise, economic growth has been painful for many; but designers owe much of their current status to it.

It's time that designers recognised these facts - and changed their thinking accordingly.

\section{About the Author}

\section{Prof. James Woudhuysen}

Work: Future of innovation, especially in energy, IT, medicine, leisure, construction/cities, the workplace. Interests: US, Asia. Background: Helped install Britain's first computercontrolled car park, 1968, before graduating in physics. Editor, Design, 1979-82; co-founder, Blueprint magazine. Instruction manual for word processing, 1983; multi-client study on ecommerce, Fitch, 1988; proposal for Web TV, Henley Centre for Forecasting, 1993. Chief, worldwide market intelligence, Philips Consumer Electronics, the Netherlands, 1995-7. Director, designers Seymour Powell, 1997-2001. Publications: Why is construction so backward? (2004); Energise! A future for energy innovation (2009); Big Potatoes: the London Manifesto for Innovation (2010). Clients: Akzo, Amadeus, Baxi Group, Brother, Geothermal Engineering, International Federation of Automotive Engineering Societies, Konecranes, Orange, Mitsubishi, Novartis, Roca, SAP, Siemens. Has written for Applied Ergonomics, Computing, Cultural Trends, The Economist, The Institute of Mechanical Engineers Journal, Long Range Planning, New Civil Engineer, The Times and The Guardian. Contributes to BBC Radio 4 and www.spiked-online.com. Website: www.Woudhuysen.com

\footnotetext{
${ }^{81}$ On this point, see for example James Woudhuysen, 'Mission creep - the limits of design', transcript of a speech given to the Intersections 2007 conference on design, Newcastle, October 2007, on http://www.designcouncil.org.uk/resources-and-events/designers/intersections-071/the-limits-of-design
} 


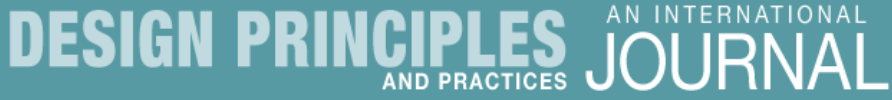

\section{Editor}

Bill Cope, University of Illinois, Urbana-Champaign, USA.

\section{Editorial Advisory Board}

Genevieve Bell - Intel Corporation, Santa Clara, USA.

Michael Biggs - University of Hertfordshire, Hertfordshire, UK.

Thomas Binder - Royal Danish Academy of Fine Arts, Copenhagen, Denmark.

Jeanette Blomberg - IBM Almaden Research Center, San Jose, USA.

Eva Brandt - Danmark Designskole, Copenhagen, Denmark.

Peter Burrows - RMIT University, Melbourne, Australia.

Monika Büscher - Lancaster University, Lancaster, UK.

Patrick Dillon - Exeter University, Exeter, UK.

Michael Gibson - University of North Texas, Denton, USA.

Mary Kalantzis - University of Illinois, Urbana-Champaign, USA.

Loredana Di Lucchio - Sapienza Universita di Roma, Rome, Italy.

Judith Gregory - IIT Institute of Design, Chicago, USA; University of Oslo, Norway.

Clive Holtham - City of London University, London, UK.

Lorenzo Imbesi, Carleton University, Ottawa, Canada.

Hiroshi Ishii - MIT Media Lab, Cambridge, USA.

Gianni Jacucci - University of Trento, Trento, Italy.

Klaus Krippendorff - University of Pennsylvania, Philadelphia, USA.

Terence Love - Curtin University, Perth, Australia.

Bill Lucas - MAYA Fellow, MAYA Design, Inc., Pittsburgh, USA.

Ezio Manzini - Politecnico of Milano, Milan, Italy.

Mario Minichiello - Birmingham Institute of Art and Design, Birmingham, UK.

Julian Orr - Work Practice \& Technology Associates, Pescadero, USA.

Mahendra Patel - Leaf Design, Mumbai, India.

Toni Robertson - University of Technology Sydney, Sydney, Australia.

Terry Rosenberg - Goldsmiths, University of London, London, UK.

Keith Russell - University of Newcastle, Callaghan, Australia.

Liz Sanders - Make Tools, USA.

Maria Cecilia Loschiavo dos Santos - University of São Paulo, São Paulo, Brazil.

Lucy Suchman - Lancaster University, Lancaster, UK.

Ina Wagner - Technical University of Vienna, Vienna, Austria.

Please visit the Journal website at http://www.Design-Journal.com for further information about the Journal or to subscribe. 


\section{The Design Principles \& Practices Community}

This knowledge community is brought together by a shared interest in the process of design and their conceptual foundations. The community interacts through an innovative, annual face-to-face conference, as well as year-round virtual relationships in a weblog, peer reviewed journal and book imprint - exploring the affordances of the new digital media. Members of this knowledge community include academics, designers, administrators, educators, consultants and research students.

\section{Conference}

Members of the Design Community meet at the International Conference on Design Principles and Practices, held annually in different locations around the world. The Design Conference was held at Imperial College London, in 2007; in conjunction with the University of Miami, Florida, USA in 2008; at Technical University Berlin, Germany in 2009; at the University of Illinois at Chicago, USA in 2010; and at Sapienza University of Rome, Italy in 2011. In 2012, the conference will be held at the University of California, Los Angeles, USA.

Our community members and first time attendees come from all corners of the globe. Intellectually, our interests span the breadth of the field of design. The Conference is a site of critical reflection, both by leaders in the field and emerging scholars and practitioners. Those unable to attend the Conference may opt for virtual participation in which community members can either submit a video and/or slide presentation with voice-over, or simply submit a paper for peer review and possible publication in the Journal.

Online presentations can be viewed on YouTube.

\section{Publishing}

The Design Community enables members of its community to publish through three media. First, by participating in the Design Conference, community members can enter a world of journal publication unlike the traditional academic publishing forums - a result of the responsive, non-hierarchical and constructive nature of the peer review process. Design Principles and Practices: An International Journal provides a framework for double-blind peer review, enabling authors to publish into an academic journal of the highest standard.

The second publication medium is through the book series On Design, publishing cutting edge books in print and electronic formats. Publication proposals and manuscript submissions are welcome.

The third major publishing medium is our news blog, constantly publishing short news updates from the Design Community, as well as major developments in the field of design. You can also join this conversation at Facebook and Twitter or subscribe to our email Newsletter. 